\title{
ASSESSMENT OF COST EFFICIENCY OF ROCK AGGREGATES PRODUCTION IN SELECTED QUARRIES IN SOUTH WEST, NIGERIA
}

\author{
Melodi M.M., Onipede T.G., Oluwafemi V.I. \\ Department of Mining Engineering, \\ Federal University of Technology, Akure, Ondo State, Nigeria.
}

\begin{abstract}
This research aimed to analyze the cost efficiency of rock aggregates production in selected quarries in South West, Nigeria with a view to predict economic efficiencies using stochastic frontier cost function. Primary data were collected from 18 operational quarries from Oyo, Ogun and Ondo States, six quarries were selected from each State. The average production cost of granite stone produced by the quarries was $\$ 1,195.353,806.30$ with standard deviation of $503,322,512$. Among various factors, cost of drilling by quarries accounted for the highest share in the production cost followed by use of explosives and repaired of machineries, they accounted for $26.86 \%, 24.49 \%$ and $\mathbf{2 2 . 9 0 \%}$ of the total cost of production. The MaximumLikelihood (ML) estimates of the parameters of the stochastic cost frontier model revealed that cost of diesel, cost of explosives, cost of repairs, tax payment, cost of drilling and payment of salaries gave positive coefficient and were significant at $1 \%$ level while the estimated coefficient of royalties payment, petrol and miscellaneous cost were not significant at 5\% level. From the analysis of scale effect among quarries, it was concluded that the quarry companies experienced an increasing return to scale. It is therefore recommended that Government should give grants and loans to finance quarry operation since it will help to improve the economy of the country and reduce unemployment rate.
\end{abstract}

Keywords: aggregates, efficiency, quarry, granite, cost

\section{INTRODUCTION}

Quarry operation is the most practiced surface mining activity in Nigeria also in the world. This involves the production of dimension stones and aggregates for construction, ornamental and interior decoration purposes. Rocks like granite, limestone, marble, dolomite etc. are extracted for production of different sizes aggregates and slabs (Ashmole and Motloung, 2008). In locating economically viable deposit for aggregates production, the factors to be examined include, the tonnage available, mineable quality of aggregate, nearness to market or distance from major use areas, transportation cost, government regulation and the operating cost.

The process of producing rock aggregates involves removal of overburden, drilling of holes for blasting, blasting of the drilled holes, hauling of the blasted rocks for crushing, crushing and screening of the materials into various sizes (Saliu and Haleem, 2012).

Each of this basic cycle operation needs to be subjected to economic analysis. Ian Range (1998) stated that the complete task of planning and operating a quarry involves at least three components which include a technical component, a narrowly focused economic component and a more broadly based economic component.

The technical component includes the quarry layout, the equipment productivities, alternative production schedule and quarry operating requirement. (Dolley, 2008). These requirements includes the explosives usage per year, the number of personnel used and fuel consumption per machinery per operating hour (Saliu and Akande, 2007). This component of a quarry plan is unchanged whether the quarry is economical or not as they are basically refer to as the fixed input. The technical component defined all important element needed for the implementation of the quarry project.

The narrowly focused economic component considers the operating and capital costs to the technical schedule (Emerson, 1984). It analysis the alternatives schedules and alternatives equipment in economic term e.g. the price of a ton of aggregates, it also develop and considers the unit cost, like the fuel per litre, annual cost for the whole mine and labour cost per person per year (Jamie, 1997). The more broadly based economic, financial and business component studied the extent of viability of a granite quarrying plan and how the plan fits within a wider corporate context and also to examine the associated risk with the quarry decision.

The general economic profitability of any quarry from a production view point is mainly tested through cost efficiency analysis. Opafunso and Ajaka (2005) noted that the financial analysis of the quarrying production will appraise the financial projection, determine the economic production levels and cost 


\section{International Journal of Engineering Applied Sciences and Technology, 2020 Vol. 4, Issue 9, ISSN No. 2455-2143, Pages 391-398 \\ Published Online January 2020 in IJEAST (http://www.ijeast.com)}

efficiency effects with a view to justifying the financial feasibility of the quarry.

Many factors account for the low productivity of granite stone in Nigeria. The limited adoption of high class production technology, inadequate employee training, government policies, inadequate financing, high cost of and inadequate equipment, poor product pricing and poor remuneration of employee are some of the major factors responsible for the lower yield in the study area. In order to alleviate poverty especially among quarry communities and employees it is imperative to recognize the factors that hinder production cost efficiency in granite stone production and further quantify the extent to which they limit the cost efficiency of quarries. Ogundari et al., (2006) said an improvement in the understanding of the level of cost efficiency and its relationship with the granite stone quarries can greatly aid policy makers in creating efficiency enhancing policies also in examination of the efficiency of the present and past reforms. This study therefore analyses the productivity and cost efficiency of granite stone quarries to identify the importance of each factor of cost efficiency and to detect if there is the presence of cost inefficiency of granite stone production using the stochastic frontier cost function. This study will help to introduce a new dimension to quarries and policy makers on how to increase granite stone production by determining the extent to which it is possible to raise the efficiency of granite stone quarries with the existing resources base and the available technology in Nigeria.

The aim of the research work is to assess the cost efficiency of granite stone production in Ondo, Oyo and Ogun states. The specific objectives of the research are to examine the demographic and operational characteristics of the selected quarries in the study areas; determine the profitability of granite stone production in the study areas; evaluate the factors affecting cost efficiency in granite production; estimate the cost efficiency of the selected quarries in the study areas; and examine the production constraints of granite stone production in the study areas.

The research serves as a guide to public policy design and implementation in the country, to educate employee by organizing program and training for them to develop their career for long time which will have a great impact in increasing the level of efficiency, to optimize quarries operation and hence to increase granite stones production.

A total of eighteen operational quarries are selected in Ondo, Oyo and Ogun States. Six quarries are selected from each State.

A production function describes the technical relationship that transforms inputs (resources) into outputs (commodities) at a given level of technology (Debertin, 1986). The analysis of the efficiency of a quarry operation dates back to the scholarly work of Koopmans (1951) in which efficiency was defined as the relationship between input-use and output, and use of coefficients of resource utilization as measurement of efficiency. However, Farrel (1957) explained that efficiency of a quarry operation consists of technical, allocative and economic components. Technical efficiency is known as the ability to produce a given level of a product output with a minimum quantity of inputs under a certain technology. Allocative efficiency refers to the ability to choose optimum input levels for a given factor prices while economic or total efficiency is the product of technical and allocative efficiencies. However, Aigner et al., (1977) proposed a stochastic frontier production function approach which measures efficiency of a quarry in accordance to production frontier denoting maximum output that is technologically feasible for a given set of inputs and a benchmark of optimum production. The model is known with error term with two components; the stochastic component (Vi) and the inefficiency of the producer (Ui). While the stochastic error term represents random shocks such as adverse weather and other factors beyond the control of a quarry operator, the inefficiency component constitutes a deviation from the production frontier as a result of the operator's inefficiency. Battese and Coelli (1995) extended the stochastic production frontier model by suggesting that the inefficiency effects can be expressed as a linear function of the explanatory variables, reflecting individual producer's characteristics. The advantage of this model is that it allows estimation of the quarry-specific efficiency scores and the factors explaining efficiency differentials among quarries in a single stage estimation procedure.

The operation of channel separation is applied on the watermarked color image to generate its sub images, and then 2-level discrete wavelet transform is applied on the sub images to generate the approximate coefficients and detail coefficients.

\section{METHODOLOGY}

The information for this study was gathered through distribution of questionnaire, interview, assessment of Company's account record and library research. The study collected data about the quantity of rock blasted per month, cost of drilling accessories used, cost of explosive used, cost of maintenance of plant/equipment, cost of manpower, miscellaneous expenses and average selling price per ton of aggregate. These were supported by distribution and assessment of questionnaire to Quarry Manager to acquire necessary data such as Personnel, production schedule, production rate, production cost, and remuneration/emoluments with their salary.

Descriptive and inferential statistical were used to analyze the data. The descriptive statistics employed include frequency counts, percentages, mean and standard deviation while the inferential statistics include multiple regression analysis based on Cobb-Douglas functional form.

For the purpose of the statistical analysis, profitability model and stochastic frontier cost function based on Battese and Coelli (1995) with the behavior inefficiency component were 


\section{International Journal of Engineering Applied Sciences and Technology, 2020 \\ Vol. 4, Issue 9, ISSN No. 2455-2143, Pages 391-398 \\ Published Online January 2020 in IJEAST (http://www.ijeast.com)}

specified for this study. To carry out the profitability model, the following processes were followed.

\section{Gross Margin Analysis}

Gross margin was used to determine the cost and return as well as the profitability of granite stone production in the study area.

The Gross Margin (MG) is specified as:

$G M=T R-T V C$

Alternatively,

$\mathrm{GM}=\sum_{i=1}^{N} P_{i} Q_{i}-\sum_{j=1}^{N} C_{j i} X_{j i}$

Where:

Subscript i refers to the observation of the i-th granite stone quarry and,

TR is the Total Revenue accruing to the i-th granite stone quarries in the study area.

TVC is the Total Variable Cost incurred by the i-th granite stone quarries in the study area.

$P_{i}$ is the Average price of the granite stone from the i-th quarry in the study area.

$\mathrm{Q}_{\mathrm{i}}$ is the Quantity produced by the i-th quarry in the study area.

$\mathrm{C}_{\mathrm{i}}$ is the Average price of inputs used in the i-th quarry in the study area.

$\mathrm{X}_{\mathrm{i}}$ is the Quantity of input used in the i-th granite stone quarry in the study area.

If $\mathrm{GM}>0$, the quarry enterprise is profitable

If $\mathrm{GM}<0$, the quarry enterprise is not profitable

\section{Analysis of Stochastic Frontier Cost Model}

To carry out the stochastic frontier cost function analysis, the model is implicitly expressed as:

$\ln C i=g\left(P i, Y_{x}, \alpha\right)+(V i+V i)$

where $\mathrm{C} i$ represents the total cost of production, $\mathrm{g}$ is a suitable functional form such as the Cobb-Douglas; $\mathrm{Pi}$ is the vector variable of input prices such as machinery/equipment, power supply, skilled and unskilled labour, explosive consumption, petrol and diesel consumption. Yi is the value of granite stone produced in tons, $\alpha$ is the parameter to be estimated. The systematic component $\mathrm{Vi}$ represents the random disturbance costs due to the factors outside the scope of quarry. it is assumed to be identically and normally distributed mean zero and constant variance as $N\left(0, \sigma^{2} v\right) . \mathrm{Ui}$ is the one-sided disturbance form used to represent cost inefficiency and is independent of $\mathrm{Vi}$. Thus, $\mathrm{Ui}=0$ for a quarry whose costs lie on the frontier, Ui $>0$ for quarries whose cost is above the frontier, $\mathrm{Ui}<0$ for quarry identically and independently distributed as $\mathrm{N}\left(0, \sigma^{2} \mathrm{v}\right)$. The two error terms are proceeded by positive signs because inefficiencies are always assumed to increase cost. Furthermore, the cost efficiency of an individual granite stone operation is defined in the terms of the ratio of the observed cost $\left(\mathrm{C}^{\mathrm{b}}\right)$ to the corresponding minimum cost $\left(\mathrm{C}^{\mathrm{min}}\right)$ given the available technology is expressed as:
Cost Efficiency $\left(\mathrm{C}_{\mathrm{EE}}\right)=\frac{c^{\ominus}}{c^{\min }}=\frac{g\left(p_{i} Y_{\hat{L}_{i}}\right)+\left(V_{i}+U_{\hat{i}}\right)}{g\left(p_{i}, Y_{i}, \alpha\right)+\left(V_{i}\right)}=\exp \left(U_{i}\right)$

where the observed cost $\left(C^{b}\right)$ represents the actual production cost whereas the minimum cost $\left(\mathrm{C}^{\mathrm{min}}\right)$ represents the frontier total production cost or the least total production cost level. $\mathrm{C}_{\mathrm{EE}}$ takes the values between 1 or higher with 1 defining cost efficient quarry according to Ogundari et al., (2006).

The inefficiency model (Ui) is defined as;

$U_{i}=\alpha_{\circ}+\alpha_{1} Z_{1}+\alpha_{2} Z_{2}+\alpha_{a} Z_{a}+\alpha_{4} Z_{4}+\alpha_{5} Z_{5}$ (5)

Where $Z_{1}, Z_{2}, Z_{3}, Z_{4}$ and $Z_{5}$ represents the company ownership, number of skilled staff, number of unskilled staff, working hours per day, extent of focus on granite stone production as primary operation. The socio-economic variables are included in the model to indicate their possible influence on the cost efficiency of the granite stone quarries. The variance of the random error $\sigma^{2} \mathrm{v}$ and that of the cost inefficiency effects $\sigma^{2} \mathrm{u}$ and the overall variance of the model $\sigma^{2}$ are related as: $\gamma=$ $\sigma^{2} \mathrm{u} / \sigma^{2} \mathrm{v}+\sigma^{2} \mathrm{u}$, where $\gamma$ measures the total variation of the total cost of production from the frontier cost which can be attributed to cost inefficiency (Battese, Corra 1977), hence, following the adoption of Battese and Coelli (1995) framework for the analysis of the data, the explicit CobbDouglas functional for the granite stone quarries in the study area is therefore specified as:

$\ln C i=\alpha_{0}+\ln \omega_{\circ}+\alpha 1 \ln P 1 i+\alpha 2 \ln P 2 i+\alpha 3 \ln P 3 i+$ $\alpha 4 \ln P 4 i+\alpha 5 \ln P 5 i+\alpha 6 \ln P 6 i+\alpha 7 \ln P 7 i+\alpha 8 \ln P 8 i+$ $\alpha 9 \ln Y i+(V i-i)$

Where:

$\mathrm{C} \mathrm{i}$ is Total cost of production; $\mathrm{P}_{1 \mathrm{i}}$ is Cost of diesel; $\mathrm{P}_{2 \mathrm{i}}$ is Cost of petrol; $\mathrm{P}_{3 \mathrm{i}}$ is Cost of explosives; $\mathrm{P}_{4 \mathrm{i}}$ is Cost of equipment repairs; $\mathrm{P}_{5 \mathrm{i}}$ is Payment of salaries; $\mathrm{P}_{6 \mathrm{i}}$ is Tax; $\mathrm{P}_{7_{\mathrm{i}}}$ is Cost of drilling; $\mathrm{P}_{8 \mathrm{i}}$ is Royalties; $\mathrm{P}_{9 \mathrm{i}}$ is Miscellaneous expenses; $\mathrm{Vi}$ is Random errors; Ui is Technical inefficiency effects; $\mathrm{Yi}$ is output of quarry in tons; $\mathrm{Vi}$ and $\mathrm{Ui}$ are assumed to be independently distributed of each other and uncorrelated with $\mathrm{Xi}$, while Ui follows half normal distribution.

The estimate for all the parameters of the stochastic frontier cost function and the inefficiency model are simultaneously obtained using the computer program FRONTIER 4.1 program (Coelli, 1996).

\section{RESULTS AND DISCUSSIONS}

The results of data analysis carried out and their discussions are presented in the tables.

3.1 Demographic and Operational Characteristics of the Selected Quarries

Table 1 gives the nature of the company ownership while Table 2 highlights the number of subsidiary owned by the selected quarries. Also, Table 3 gives the nature of production by the selected quarries. Table 4 gives the number of skilled staff by the selected quarries. Table 5 shows the number of 
unskilled staff by the quarries while Table 6 gives the size of land owned by the quarries.

Table 1: Nature of Company Ownership

\begin{tabular}{|l|l|l|}
\hline Company Ownership & Frequency & $\begin{array}{l}\text { Percenta } \\
\text { ge }\end{array}$ \\
\hline Indigenous Quarry & 3 & 16.7 \\
\hline Foreign Quarry & 15 & 83.3 \\
\hline Total & 18 & 100.0 \\
\hline
\end{tabular}

Table 2: Number of Subsidiary Owned by the Selected Quarries

\begin{tabular}{|l|l|l|}
\hline Number of Subsidiary & Frequency & Percentage \\
\hline One & 15 & 83.3 \\
\hline Two & 3 & 16.7 \\
\hline Total & 18 & 100.0 \\
\hline
\end{tabular}

Table 3: Nature of Production by the Selected Quarries

\begin{tabular}{|l|l|l|}
\hline $\begin{array}{l}\text { Production of Granite } \\
\text { Stone only }\end{array}$ & Frequency & Percentage \\
\hline No & 9 & 50.0 \\
\hline Yes & 9 & 50.0 \\
\hline Total & 18 & 100.0 \\
\hline
\end{tabular}

Table 4: Number of Skilled Staff by the Selected Quarries

\begin{tabular}{|l|l|l|}
\hline $\begin{array}{l}\text { Number of skilled } \\
\text { staff }\end{array}$ & Frequency & Percentage \\
\hline $11-15$ & 8 & 44.5 \\
\hline $16-20$ & 6 & 33.3 \\
\hline $21-25$ & 4 & 22.2 \\
\hline Total & 18 & 100.0 \\
\hline
\end{tabular}

Table 5: Number of Unskilled Staff by the Quarries

\begin{tabular}{|l|l|l|}
\hline $\begin{array}{l}\text { Number of unskilled } \\
\text { staff }\end{array}$ & Frequency & Percentage \\
\hline $16-25$ & 3 & 16.7 \\
\hline $26-35$ & 7 & 38.9 \\
\hline $36-45$ & 8 & 44.4 \\
\hline Total & 18 & 100.0 \\
\hline
\end{tabular}

Table 6: Size of Land by the Quarries

\begin{tabular}{|l|l|l|}
\hline Size of Land (Hectare) & Frequency & $\begin{array}{l}\text { Percentag } \\
\text { e }\end{array}$ \\
\hline Below 40 & 4 & 22.2 \\
\hline $40-60$ & 7 & 38.9 \\
\hline Above 60 & 7 & 38.9 \\
\hline Total & 18 & 100.0 \\
\hline
\end{tabular}

\subsection{Analysis of Production Variables}

The summary statistics of the production variables obtained from Granite Stone Quarries in the study area. The average production cost of granite stone produced by the quarries was $\mathbf{N 1} 195,353,803.30$ / quarry with the standard deviation of \$503,322,512 during the five (5) years studied period. The average cost of production items and their corresponding standard deviation estimates are also displayed in the Table. As earlier discussed, the costs of drilling and cost of

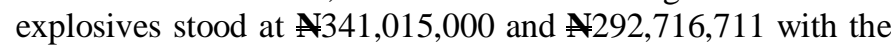
standard deviation of $\mathbf{1 3 6 , 4 0 6 , 0 0 0}$ and $\mathbf{1 1 7 , 0 7 5 , 1 7 8}$ respectively. The high standard deviation obtained for the two cost variables suggests that there was a wide variation in the level of production costs incurred by individual quarry. This finding may be attributed to the different production capacity of the quarries which made them to operate at different levels of costs of production.

The socio-demographic variables of the quarries in terms of number of skilled and unskilled staff were also captured in the table. The result shows that the average number of skilled staff per quarry was 17 with the standard deviation of 5 while that of unskilled staff had a mean value of 33 with the standard deviation of 7 . The mean number of working hours per day was 11 with the standard deviation of 0 . This shows that all the selected quarries in study area were operating the same number of working hours per day.

\subsection{Profitability Analysis}

This section explains the profitability performance granite stone production with respect to average gross margin.

\subsubsection{Analysis of the Quarries' Production Cost.}

The distribution of the studied quarries by the average cost of production is presented in Table 8 , the table revealed that the major cost of production was incurred on the drilling of holes (\$321,015,000) and purchase of explosives (\$292,716,711) as they accounted for $26.86 \%$ and $24.49 \%$ of the total cost of production respectively. About $22.90 \%$ of the total cost of production was incurred on repairs of machineries while the payment of salaries shared $14.43 \%$ of the total cost of granite stone production by the quarries in the study area. The percentage share of other production costs such as cost incurred on diesel, Royalties, Petrol and Tax stood at $6.66 \%$, $1.89 \%, 1.43 \%$ and $0.1 \%$ of the total production costs respectively. The Miscellaneous cost only accounted for just $1.24 \%$ of the total production cost. What can be easily deduced from this finding is the fact that drilling of holes and the explosive being used for detonation are important determining factors in granite stone production in the study area.

Table 8: Analysis of the Quarries' Production Cost.

\begin{tabular}{|l|l|l|}
\hline Variable (Item) & Mean (N) & Percentage (\%) \\
\hline Cost of diesel & $79,661,967.00$ & 6.66 \\
\hline Cost of Petrol & $17,113,756.00$ & 1.43 \\
\hline Cost of Repairs & $273,765,217.00$ & 22.90 \\
\hline
\end{tabular}




\begin{tabular}{|l|l|l|}
$\begin{array}{l}\text { Payment of } \\
\text { salaries }\end{array}$ & $172,453,889.00$ & 14.43 \\
\hline Royalties & $22,619,583.00$ & 1.89 \\
\hline Tax of & $1,174,306.00$ & 0.10 \\
\hline $\begin{array}{l}\text { Cost of } \\
\text { Explosives }\end{array}$ & $292,716,711.00$ & 24.49 \\
\hline Cost of Drilling & $321,015,000.00$ & 26.86 \\
\hline $\begin{array}{l}\text { Cost Variable } \\
\text { Miscellaneous }\end{array}$ & $14,833,378.00$ & 1.24 \\
\hline $\begin{array}{l}\text { Total } \\
\text { Cost }\end{array}$ & $1,195,353,806.30$ & 100.00 \\
\hline
\end{tabular}

\subsubsection{Gross Margin Analysis}

Gross margin is the total revenue less total variable cost and this was shown in Table 9. The findings revealed that a sum of $11,829,705.167$ on the average was obtained by the Granite Stone quarries as revenue in the study area. While the average variable cost incurred by the Granite Stone Quarries was $¥ 1,195,353,806.3$, the mean gross margin was estimated to be $\$ 634,351,358.70$. This result implies that on the average, Granite Stone Quarry in the study area was able to cover its operating expenses and make substantial profit, hence it can be deduced that Granite Stone production in the study area is profitable and worth investing on.

\subsection{Productivity Analysis}

This section focuses on the analysis of productivity of the selected quarries in the study areas.

\subsubsection{Estimate of Stochastic Frontier Cost Function model}

The maximum-likelihood (ML) estimates of the parameters of the stochastic cost frontier models were obtained using the computer program STATA. The parameter estimates of the frontier cost function as reported in Table $\mathrm{X}$ shows the estimates of parameter coefficients and their corresponding levels of significance. The associated signs on the estimated parameters show that variables such as cost of diesel, cost of explosives, cost of repairs, tax, cost of drilling, and payment of salaries had positive or direct relationship with total production cost. This means that an increase in the level of these production variables will lead to increase in the production cost. The signs on the parameter coefficients on costs of petrol and royalties were however negative, which implies an inverse relationship with the total production cost. Furthermore, the estimated coefficients of the parameters and associated test statistics show that the coefficients of variables such as cost of diesel, cost of explosives, cost of repairs, tax, cost of drilling and payment of salaries were statistically significant at $1 \%$ level; Hence these variables are the important determinants for granite stone production in the study area. It would be observed that the estimated parameter coefficients of cost of petrol, royalties and miscellaneous cost were not significant at the conventional 5\% level of significance. Hence these variables are considered less important for granite stone production in the study area.

Since the cost function is a function of all input prices, the percentage increase in the total production is based on the interpretation of the coefficient of the Cobb-Douglas function as the elasticity of production. In this case, the coefficients of the cost function serve as the cost elasticity of the production. Hence, $1 \%$ increase in the cost of diesel for example will increase the total production cost by $0.1568 \%$. Similarly, $1 \%$ increase in cost of explosives will increase the total production cost by $0.2345 \%$, while $1 \%$ increase in tax will increase the total production cost by $0.1061 \%$, also $1 \%$ increase in the cost of drilling will increase the production cost by $0.2477 \%$, also $1 \%$ increase in payment of salaries will increase the production cost by $0.2322 \%$ and $1 \%$ increase in the cost of repairs will increase the production cost by $0.2780 \%$. The estimated sigma square value $(0.0042)$ of granite stone production in the study area is significantly different from zero at $1 \%$. This shows a good fit of the model.

Table 10 : Maximum - likelihood Estimates of Parameters of Stochastic Frontier Cost Model for Granite Stone Production in the Study Areas

\begin{tabular}{|c|c|c|c|}
\hline Variable & $\begin{array}{l}\text { Para } \\
\text { meter } \\
\mathrm{s}\end{array}$ & $\begin{array}{l}\text { Esti } \\
\text { mat } \\
\text { es }\end{array}$ & $\begin{array}{l}\mathrm{t}- \\
\text { value }\end{array}$ \\
\hline $\begin{array}{l}\text { General Model } \\
\text { Constant } \\
\text { Cost of diesel } * * * \\
\text { Cost of petrol } \\
\text { Cost of Repairs *** } \\
\text { Payment of } \\
\text { Salaries*** } \\
\text { Royalties } \\
\text { Tax *** } \\
\text { Cost } \\
\text { Explosives*** } \\
\text { Cost of Drilling } * * * \\
\text { Miscellaneous cost }\end{array}$ & $\begin{array}{l}\beta 0 \\
\beta 1 \\
\beta 2 \\
\beta 3 \\
\beta 4 \\
\beta 5 \\
\beta 6 \\
\beta 7 \\
\beta 8 \\
\beta 9\end{array}$ & $\begin{array}{l}0.23 \\
19 \\
0.15 \\
68 \\
- \\
0.72 \\
26 \\
0.27 \\
80 \\
0.23 \\
22 \\
- \\
0.33 \\
48 \\
0.10 \\
61 \\
0.23 \\
45 \\
0.24 \\
77 \\
- \\
0.15 \\
37\end{array}$ & $\begin{array}{l}8.425 \\
4.396 \\
6 \\
- \\
0.033 \\
8 \\
13.08 \\
45 \\
10.37 \\
70 \\
0.891 \\
7 \\
3.587 \\
8 \\
12.00 \\
63 \\
14.67 \\
62 \\
- \\
0.103 \\
9\end{array}$ \\
\hline $\begin{array}{l}\text { Diagnostic statistics } \\
\text { Sigma-square } * * * \\
\text { Gamma**** } \\
\text { Log likelihood } \\
\text { function }\end{array}$ & $\begin{array}{l}\sigma^{2} \\
\gamma\end{array}$ & $\begin{array}{l}0.00 \\
42 \\
0.98 \\
79\end{array}$ & $\begin{array}{l}4.780 \\
8 \\
12.99 \\
85\end{array}$ \\
\hline
\end{tabular}




$\begin{array}{ll}\text { LR test of one-sided } & 52.7 \\ \text { error } & 390 \\ & 7.66 \\ & 59\end{array}$

$* * *, * *$ and $*$ variables with significant estimates at $1 \%$, $5 \%$ and $10 \%$ levels respectively

\subsubsection{Cost Inefficiency Analysis}

The estimated coefficients in the inefficiency model presented in Table 11 have important implications on the cost efficiency of the granite stone quarries in the study area. Therefore the main purpose of cost inefficiency model is to analyze the cost efficiency of the studied quarries. So, the model is assumed to be the representation of the data considering its highly significant Sigma-square value as well as the Log Likelihood function under the half-normal distribution assumed with the maximum likelihood techniques. The cost efficiency analysis of granite stone quarries in the study area revealed that there was the presence of cost inefficiency effects in granite stone production as confirmed by the significant gamma value of 0.9879 at $1 \%$ level. This implies that about $99 \%$ of the variation in the total cost of production among the sampled quarries was due to the differences in their cost efficiencies.

The model results revealed that the estimated parameters of variables such as number of unskilled staff and granite production as primary work had negative coefficients which were significant at $1 \%$ level. This implies that for example, with $1 \%$ increase in the number of unskilled staff, the level of cost inefficiency of the granite stone quarries will reduce by $0.0034 \%$ (i.e cost efficiency increases). Likewise, engaging in granite stone production as primary work also reduces cost inefficiency among the granite stone quarries. This finding underscores the importance of unskilled labour in granite stone production since they are used to carry out major works in the quarries at more or less cheaper cost compared to skilled staff. Also, quarries that are into granite stone production as a primary work will be able to harness all their resources for efficient production when compare with those that did it as secondary job.

Table 11: Technical Inefficiency factors

\begin{tabular}{|c|c|c|c|}
\hline Variable & $\begin{array}{l}\text { Para } \\
\text { meter } \\
\mathrm{s}\end{array}$ & $\begin{array}{l}\text { Esti } \\
\text { mate } \\
\mathrm{s}\end{array}$ & $\begin{array}{l}\mathrm{t}- \\
\text { value }\end{array}$ \\
\hline \multicolumn{4}{|l|}{ Inefficiency Model } \\
\hline Constant & So & 0.23 & 8.425 \\
\hline Company ownership & $\delta 1$ & 19 & 0 \\
\hline Number of skilled & $\delta 2$ & 0.02 & 1.390 \\
\hline staff & 83 & 89 & 5 \\
\hline Number of unskilled & 84 & 0.00 & 0.855 \\
\hline staff $* * *$ & 65 & 11 & 8 \\
\hline Working hours per & & - & - \\
\hline day* & & 0.00 & 3.503 \\
\hline Granite production as & & 34 & 5 \\
\hline primary work $* * *$ & & 0.00 & 1.801 \\
\hline
\end{tabular}

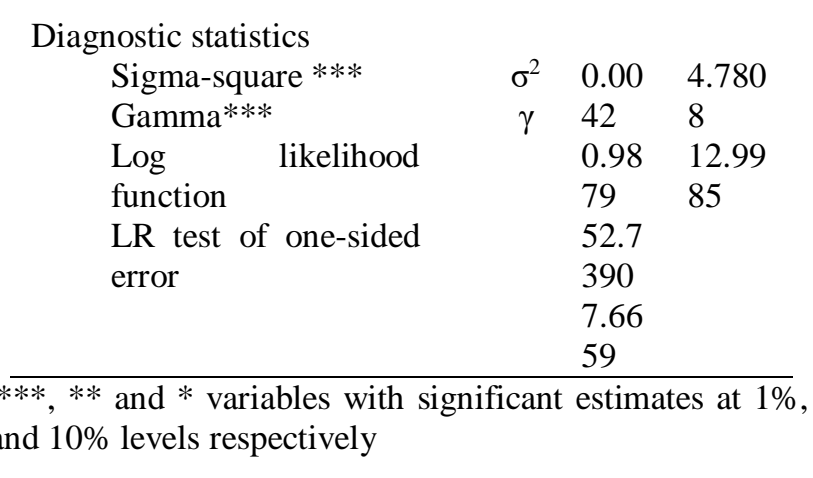

\subsubsection{Distribution of Cost Efficiency Estimates}

The cost efficiency scores for the granite stone quarry in the study area are presented in Table XII. The predicted cost efficiencies (CEE) ranged from 1.1001 to 1.1122 . The mean cost efficiency of an average granite stone quarry was estimated at 1.1024 , meaning that an average quarry company in the study area incurred costs that are about $0.21 \%$ above the minimum cost defined by the frontier. That is, only about $0.21 \%$ of the granite stone production cost was wasted by an average quarry in comparison to the best practice quarry producing the same output and facing the same economic situations in the study area. The higher the cost efficiency scores of a quarry relative to 1 , the more inefficient the quarry is during the course of granite stone production. This indicates that the majority of granite stone quarries in the study area are relatively cost efficient but still need to minimize the waste of resources associated with granite stone production process.

Table 12: Cost Efficiency Estimates of the Selected Quarries

\begin{tabular}{ccc}
\hline Quarry & Cost Efficiency & Rank \\
\hline 1 & 1.1039 & 16 \\
2 & 1.1020 & 9 \\
3 & 1.1011 & 8 \\
4 & 1.1018 & 4 \\
5 & 1.1004 & 13 \\
6 & 1.1122 & 6 \\
7 & 1.1051 & 15
\end{tabular}


International Journal of Engineering Applied Sciences and Technology, 2020

Vol. 4, Issue 9, ISSN No. 2455-2143, Pages 391-398

Published Online January 2020 in IJEAST (http://www.ijeast.com)

$\begin{array}{llc}8 & 1.1001 & 11 \\ 9 & 1.1030 & 7 \\ 10 & 1.1025 & 10 \\ 11 & 1.1002 & 5 \\ 12 & 1.1001 & 18 \\ 13 & 1.1046 & 17 \\ 14 & 1.1018 & 1 \\ 15 & 1.1015 & 14 \\ 16 & 1.1004 & 12 \\ 17 & 1.1029 & 3 \\ 18 & 1.1005 & 2\end{array}$

Mean $=1.1024$, Minimum $=1.1001$, Maximum $=$ 1.1122

Standard deviation $=0.0029$

\subsection{Constraints to granite stone production}

This section presents the analysis of production constraints of granite stone production in the study areas. As presented, poor pricing of granite stone was a minor constraint to most quarries in Ondo (83.3\%) and Oyo (66.7\%) states, while it oscillates between minor and major in Ogun state (50\%). Poor market system of granite stone quarries was a minor constraint in most quarries in Ondo and Oyo state $(66.7 \%)$ and oscillates between major and minor in Ogun State (50\%). Inadequate Training for quarries workers has been the major constraint affecting the efficiency of quarries operation in Ogun State $(100 \%)$ but the effect of inadequate training was within the average for quarries in Ondo and Oyo States (50\%). Protest by Quarries worker was at peak (major constraint) among quarries in Oyo and Ogun States (100\%) but oscillates between major and minor in Ondo State $(66.7 \%)$.

Communal issues were minimal in all the studied quarries. Likewise inadequate technology has little effect in smooth running of the studied quarries (minor), while inadequate capital for purchase of plants, equipment and general maintenance of quarries operation was a minor constraint affecting the operation of all the studied quarries. While the effect of weather condition was much (peak) in most quarries in Ondo and Ogun States (100\%) but minimal in most quarries in Oyo State $(83.3 \%)$. Inadequate labour also was a major constraint affecting operation of most quarries in Ogun State because most quarries in Ogun State were short- staffed (83.3\%) while the effect of inadequate labour was a minor constraint in Ondo and Oyo States (66.7\%).

\section{CONCLUSION AND RECOMMENDATIONS}

\subsection{CONCLUSION}

The aim of this research work is to assess the cost efficiency of granite stone production in Ondo, Oyo and Ogun states. The primary data pertinent to the study was collected through researcher's personal assessment of accounting records of each of the quarries and this was supported by interview and questionnaire to quarry managers to acquire necessary data such as personnel, royalties, tax, production schedule, production rate, costs of production items, and remuneration/emoluments alongside other production variables. The collected data was subjected to statistical analysis and the results discussed appropriately.

The study found out that majority $(83.3 \%)$ of the studied quarries was owned by the foreigners while only $16.7 \%$ of the quarries were owned by Nigerians. Based on analysis of production costs, the study discovered that the major cost of production was incurred on the cost of drilling ( $\mathbf{N} 321,015,000)$ and purchase of explosives ( $\mathbf{N} 292,716,711)$ as they accounted for $26.86 \%$ and $24.49 \%$ of the total cost of production respectively. The profitability analysis carried out revealed that Granite Stone Quarries in the study area, on the average were able to cover their operating expenses and made substantial profit.

The results of stochastic frontier cost model to observe productive efficiency in terms of costs of production among the selected quarries operating in the study area revealed that the estimated coefficients of cost of diesel, payment of salaries, cost of repairs, tax, cost of explosives and cost of drilling were positive and statistically significant at $1 \%$ level; while the estimated coefficient of royalties was also positive and found to be significant at 5\% level. Therefore, these variables are important determinants for granite stone production in the study area. The results of inefficiency model revealed that the coefficients of variables such as number of unskilled staff and nature of granite production (i.e granite production as primary work) had negative coefficients and were significant at $1 \%$ level. This finding therefore means that these two variables tend to reduce cost inefficiency in granite stone production process.

The minimum cost efficiency defined by the frontier was 1.1001 while the mean cost efficiency from the stochastic frontier cost function was 1.1024; indicating that about $0.21 \%$ of the granite stone costs were wasted in relation to the quarries adopting the best practices while producing at the same level of output. This indicates that majority of granite stone quarries in the study area are relatively cost efficient but still need to minimize the waste of resources associated with granite stone production process. According to the study, major production constraints faced by the studied quarries are poor marketing system, inadequate training, inadequate labour, poor weather conditions, workers' agitation and inadequate capital. Therefore, the study concludes that granite stone production in the study areas is highly profitable while 


\section{International Journal of Engineering Applied Sciences and Technology, 2020 Vol. 4, Issue 9, ISSN No. 2455-2143, Pages 391-398 \\ Published Online January 2020 in IJEAST (http://www.ijeast.com)}

the studied quarries were fairly efficient in terms of cost of granite stone production

\subsection{RECOMMENDATIONS}

This research work has shown that quarry operation is a viable business but it is capital intensive. It is therefore recommended that Government should give supportive hand by given grants and soft loans to finance quarry operations, since it will help to improve and develop the economy of the country and reduce the unemployment rate.

The issues of unrealistic public electricity supply needs to be addressed to reduce the high operating costs in the Quarry firm; this will enhance the performance of Quarry firm to contribute rapidly to the economic growth objective of the Government of Nigeria. Also With low operating cost, more employment would be generated. Local and foreign investors are encouraged to consider investing in this sector as it provides a good return on investment with a readily available market.

The enacted law guiding the operation of quarry operation should be strictly followed. Introduction of other government agencies like SSS and anti-bomb squad into quarry operation which contradict Nigerian Mineral and Mining act, 2007 and Mining regulation 2011 and also has negative effect on the production cost of the company should be reversed. Interest rate on loans from banks should be reduced to nearest minimal.

\subsection{ACKNOWLEDGEMENT}

We like to acknowledge Mr. Ogunyemi O., for is timely contribution to the reading of this work. Thank you.

\section{REFERENCES}

Aigner D., Lovell C., and Schmidt P. (1977). Formulation and estimation of stochastic frontier production models, Journal of Econometrics, 6, pp. 21-32.

Ashmole I., and Motloung, M. (2008). Dimension stone: The latest trends in exploration and production technology. The South African Institute of Mining and Metallurgy, pp. 36-70

Battese G., and Coelli T.J. (1995). A Model for Technical Inefficiency effects in stochastic frontial production for panel data. Empirical Economics, 20: pp.325-345.

Battes G., and Corra G. (1977). Estimation of a production function model with application to the pictorial zone to Eastern Australia. Australian Journal of Agricultural Economics, 21, pp.169-179.

Coelli T. (1996). "A guide to FRONTIER version 4.1c: computer program for stochastic Frontier production and cost function estimation", Working Paper, Department of Econometrics, University of New England, Armidale, pp 7.
Dolley T. (2008). Mineral Commodity Summaries: Stone (Dimension). U.S. Geological Survey, 2008, pp. 160-161.

Debertin D. (1986). Agricultural Production Economics. Macmillan Publishing Company; New York, $p p$ 54.

Emerson C. (1984). Economics Evaluation of Mineral Processing Projects P.J.Lioyd (ed) Mineral Economics in Australia, Sydney: Alen and Unwin, pp. 253-272.

Ian R. (1998). Mining Economics and Strategy, The Society for Mining, Metallurgy and Exploration, pp.7-8.

Jamie L. (1997). How to Calculate an Hourly Production Rate" available at http://smallbusiness.chron.com/calculatinghourlyproduction-rate-/922/.htm, accessed on $(2 / 10 / 2017)$

Koopmans T. (1951). 'An Analysis of Production as Efficient Combination of Activities', in Koopmans (ed): Activity Analysis of Production and Allocation, cowles Commission for Research in Economics, Monograph 13, pp 35.

Ogundari K. (2010). Estimating and Analyzing Cost Efficiency of Sawmill Industry in Nigeria: $A$ Stochastic Frontier Approach. China Agricultural Economics Review. 2(4), pp. 420- 433.

Ogundari K., Ojo S. and Ajibefun I. (2006). Economics of scale and cost efficiency in small scale maize production. Empirical evidence from Nigeria. Journal of Social Sciences, 13(2), pp 131-136

Opafunso, Z., and Ajaka, D.E. (2005). Application of Geographic Information System to Solid Mineral Resources Information Management, Nigerian Mining Journal 2005, 2, pp 30-41.

Saliu M., and Haleem, J. (2012). Investigations into Aesthetic properties of Selected Granite in South Western Nigeria as Dimension Stone, Journal of Engineering Science and Technology, 7(4), pp. 418-419.

Saliu, M., and Akande B. (2007). Drilling and Blasting Pattern Selection for Fragmentation Optimization, Journal of Engineering and Applied Sciences, pp. 1768-1769. 